\title{
KÖNYV A BUDAPESTI BESZÉDRŐL
}

Budapest nyelvhasználatának vizsgálata kemény falat, akárki (egyén vagy csoport) vállalkozik is rá. Tudniillik, a főváros lakossága a város nagyságának és szerepköreinek, nemkülönben kommunikációs sokrétüségének és dinamizmusának következtében nemcsak demográfiai és foglalkozásbeli sokféleségében, hanem beszélt nyelvében is nagyon változatos. Bárczi Géza volt az első nyelvész, aki 1932-ben a „pesti nyelvvel” célzottan foglalkozott, s szorgalmazta is az ez irányú kutatást. Mivel azonban korábban kutatócsoporti formában nem müvelték a nyelvtudományt, nem került sor a fővárosi beszélt nyelv alapos vizsgálatára. Ez csak jóval később és szociolingvisztikai keretben vált lehetségessé. Éspedig az 1985-től számítható években, amikor meggyökerezett nálunk is az új nyelvtudományi szemléletmód. Ebben oroszlánrésze Kontra Miklósnak, a jelen kötet alapjául szolgáló kutatás vezetőjének, egyszersmind ezen kötet társszerkesztőjének volt.

A bemutatandó könyvben egyrészt a magyar főváros első korszerű szociolingvisztikai beszédkorpusza létrehozásának történetéről, koncepciójáról, személyi és anyagi feltételeinek megteremtéséről, tehát a minden nagyobb, munkacsoportban folyó kutatásban fölmerülő gondokról olvashatunk hiteles és tanulságos bemutatást, másrészt tanulmányozhatjuk az adatbázis alapján készült, különböző tematikájú elemzéseket, írásokat is. Azaz: azonos forrásra visszamenő, de eltérő tematikájú tanulmányok mutatják be, mire is jó egyebek mellett a megakorpusz, néven nevezve a Budapesti Szociolingvisztikai Interjú (rövidítve BUSZI). A jól szerkesztett kötetben könnyủ eligazodni: ábrák, táblázatok, térképek, tárgy- és névmutató, egy annotált bibliográfia és egy DVD-melléklet is segítenek ebben.

A szóban forgó adatbázis és a kísérő kötet a magyarországi szociolingvisztikai kutatások egyik fontos eredménye és dokumentuma, amely további két, sikerre vitt korszerü szociolingvisztikai élőnyelvi adatbázis-építést és az azokon nyugvó elemzések, következtetések horizonttágító voltát juttatja eszünkbe. A három tudományos vállalkozás egyrészt szemléletformáló szerepe (a labovi variációs szociolingvisztika hazai meggyökereztetése), másrészt a tudományos eredmények gyakorlati alkalmazhatósága miatt fontos (iskolai oktatás, nyelvi változások, nyelvpolitika, nyelvi jogok, nyelvi tervezés, többnyelvüség). A szociolingvisztika magyarországi meghonosítása tudománytörténeti fontosságú tett volt. Az új szemléletmód eredményességét a BUSZI és - utaltam rájuk - két „testvére”, a Magyar Nemzeti Szociolingvisztikai Vizsgálat, nemkülönben A magyar nyelv a Kárpát-medencében a XX. század végén címü hatkötetes sorozat mutatja, igazol- 
ja. Kontra Miklós ezeknek a létrejöttében is nélkülözhetetlen és irányító, meghatározó szerepet játszott.

A BUSZI előzményeihez: 1985-ben indult a magyar nyelvtudomány koncepciójában a korszerű labovi variációs szociolingvisztika elvein alapuló vállalkozása, egy szociológiailag is megalapozott, modern budapesti szociolingvisztikai beszédkorpusz létrehozása. 250 magnetofonos interjú készült, szociológiai paraméterek szerint kiválasztott adatközlővel. A tudományos vállalkozás vezetője, szervezője és szakmai felelőse Kontra Miklós volt, aki negyedszázadon át az Akadémia Nyelvtudományi Intézete Élőnyelvi Osztályának volt a vezetője. A könyv a bevezető részben a BUSZI széles körü tudománytörténeti leírását adja, arra is kitérve, hogy miben hozott újat a BUSZI, milyen tudományetikai kérdések merültek fel, miként zajlott az interjúzás, a lejegyzés, a kódolás, hogyan tárolták az adatokat. A technikailag (akkor) legkorszerübb hangrögzítés hangtani, morfológiai, szintaktikai és néhány lexikai kérdés vizsgálatát is lehetővé teszi. A könyv nagyobbik részében (143-332.) a BUSZI adatbázisa alapján született elemzések olvashatók. E müfajnak van előzménye a magyar nyelvtudományban. Tudvalevő, hogy a hazai nyelvtudományban a kutatócsoportos kutatás első jelentős megvalósulása a magyar nyelvjárások atlaszának mint nyelvjárási élőnyelvi megakorpusznak a létrehozása volt. (Vö. Deme László és Imre Samu szerkesztők A magyar nyelvjárások atlaszának elméleti-módszertani kérdései, 1975.) 1985-ig sok víz folyt le a Dunán. A Kontra Miklós irányította kutatócsoport (a közreműködők száma a BUSZI esetében huszonkettő volt) mai szemmel nézve is professzionális módon működött, s nemcsak azért, mert vezetőjének közvetlen amerikai (egyesült államokbeli) tapasztalatai is bőven voltak, hanem mert szociológusokkal való együttműködésre is sor került. Fontos körülmény, hogy pályázati pénzeket rendszeresen nyert a kutatócsoport (mint utólag kiderült, okkal és joggal). Akkor is már az volt, de változatlanul ma is feltétele ez annak, hogy valamely nagyobb méretű kutatás egyáltalán elindulhasson, s hogy majd eredményt hozzon. Ezért fontos a tudománytámogatás ezen formájának a további kiszélesítése, illetőleg a tudományágakon belül az egyes részdiszciplínák támogatása is. Ha ez nem így lesz, akkor a nyelvtudomány (maradva ennél) óhatatlanul beszükül, s ennek negatív következményei a nyelvtudományt és egyetemi oktatását is sújtják (érzékelhetô ez a bolognai folyamat kezdete óta).

Röviden válaszolok arra a kérdésre, amit a Magyar Tudomány minden olvasója joggal föltesz: mi teszi fontossá, olvasásra, betekintésre érdemessé a könyvet? Egyrészt az, hogy a BUSZI korpuszának bevonásával készült tanulmányok jól mutatják, hogy az adatbázis tematikai és módszerbeli vizsgálatok színes változatosságát teszi lehetővé. Tehát rögzíthetjük: a kutatócsoport a modern szociolingvisztikai beszédadatbázis létrehozásával megteremtette a többirányú felhasználás, az új elemzések sorának lehetőségét. Másrészt az, hogy a keletkezéstörténetnek a jövőre nézve is hiteles bemutatásával képet nyerünk arról, mennyire összetett 
feladat egy nagyobb tudományos vállalkozás megvalósítása a nyelvészetben is (ez a szaporodó kutatócsoporti vállalkozások idején nem elhanyagolható).

Valamire kitérek még. Kontra Miklósban és munkatársaiban megfogalmazódott egy, az első olvasásra meglepő érzés, ti. a félelemé. Ezt olvassuk ugyanis a bevezetőben: azért kellett megírniuk ezt a könyvet, mert meg kell óvni „a feledés homályától azt a sok kutatási információt és eredményt, amit ebben a kötetben összegyüjtöttünk" (13.). Ez a félelem értelmezhető egyrészt úgy, hogy nem lesznek majd kutatók, akik a budapesti beszédkorpusz vizsgálatába fognak. A szerzői-szerkesztői félelem alapja az a körülmény is lehet, hogy a korábbi eredményes Élőnyelvi Osztály önállósága évekkel ezelőtt megszünt a Nyelvtudományi Intézetben (egy másik osztállyal vonták össze), illetőleg s elsősorban az, hogy a korábbi személyi feltételek radikálisan zsugorodtak (lásd 29., 37.). Emiatt a magyar élőnyelvi kutatások területén mutatkozó sok feladatnak a kutatócsoporti maradék nem tud megfelelni. Ebből viszont az következik, hogy a kutatások lendülete megtörik, s az érdeklődés is alábbhagy? Más, újabb témák, módszerek, adatok kötik le a fiatal kutatók figyelmét? Bizonyára sok igazság van ebben. De a jövőre gondolva, amikor a jelen nagy élőnyelvi korpuszai veszítenek újdonságukból, megemlíthető egy másik igazság is. Mit is mondott Ernst Lewy, a berlini egyetem volt általános nyelvészet professzora? Régi, mégis jó. Új, mégsem jó.

(Kontra Miklós - Borbély Anna szerkesztők: Tanulmányok a budapesti beszédröl a Budapesti Szociolingvisztikai Interjú alapján. Budapest: Gondolat Kiadó, 2021)

Kiss Jenő

az MTA rendes tagja, professor emeritus 